\title{
The Channel Islands
}

TUEE islands of the Norman archipelago have been the subject 1 of a literature more bullky than valuable. In the early part of the last century; a learned native of Jersey, Mr. Falle, who was also a canon of Durham and chaplain to King William III, contributed an account of the islands to Gibson's edition of the 'Britannia,' which he also expended into a quasi-historical acconnt of Jersey, a work that has been reproduced in the present age with copious notes by Mr. Durell. About a quarter of a centory ago a local magistrate, Mr. le Quesne, published a 'Constitutional History' of Jersey, and the story of the island has also been treated by several Bympathetic French writers. Histories of Guernsey have been produced by Jonathan Doncan and F. B. Tupper, the last named a mine of information. The whole archipelago has been described in a bolky volume by Messrs. Ansted and Latham. But most of the carrent works on the subject appear to be lacking in scientifio character. In a few there is an attempt to employ original documents and first-hand matter; bat on the whole the subject has certainly not attracted the dae amount of study from properly qualified persons. Traditions blindly accepted, anthorities garbled or misread, erroneous theories precenceived, or copied by one anthor from another; such hare, for the most part, been the characteristic features of the historical literature that has dealt with the subject of the Channel islands. The writer of these notes has to crave the indulgence of scholars for the shortcomings that may be found in them, whether dae to his own deficiencies or to those of his anthorities. The best printed materials ertant are the 'Bulletins de la Sociéte Jersiaise' (Jersey, 1874-86), and to these he would here, once for all, acknowledge his obligations.

At first sight it may seem as if the importance of the matter wrs not sufficient to require more serious treatment. But, although of amall dimensions, the little insular republics are singularly ancient and unique things, whose administration reflects considerable credit on some of our ancient statesmen in England. They present, moreover, some interesting illustrations of race questions, for they were once connected with each other and with the main- 
land, and their ethnology cannot be dissociated from that of the tract now known as 'The Cotentin.' It is even probable that the connexion extended in a southward direction, and that the Benffetins, Minquiers, and Chaussey are the landmarks of the latter junction, as the Ecrehous are of the former. The singular shape of the galf, with a straight-cut line of coast from north to south, and a rounded corner by Mont St. Michel, lends plausibility to the tradition that the Channel has worn itself a way in what is known as the 'Derroute,' and in so doing has abraded the schistose elements of the lower lands, leaving the granite bare and crumbling, the mere skeleton of a palxontologic country. The Abbe Manet, a Malonin antiquary of the early part of the present century, published a book in which he contended that this had taken place by the action of a sudden storm-rave, and so late as 709 A.D. But, judging by the analogy of other instances, such as the tidal deluges of the bay of Bengal, such a cause appears insufficient. A marine tamult of that kind may sweep away trees and houses; but it retires, and in retiring leaves the land where it was, or even perhaps raises it by a deposit of silt. ${ }^{1}$ Moreover, it has been shown by M. Chèrremont ('Mouvements du Sol') that the evidence has been entirely misread, and that the changes nct only did not occur suddenly, but involved far longer periods of time than eleven centuries. For historical purposes, then, we must assume that the islands of the Norman archipelago have long been pretty mach the same in shape and size as we see this day.

Before the beginning of historic records, nevertheless, they were doubtless joined to the mainland, and were inhabited by one and the same neolithic people. In Henri Martin's 'Etudes' (Paris, 1872) will be found some interesting descriptions and conjectures regarding the stone monuments of Brittany, to whose class those or the islands belong. M. Martin endeavours to show that they must. have been raisediby some Celtic tribe, and not by Therians, Ligurians, or prehistoric races. Two things, however, have to be explained before this riew can be accepted: one being the presence, at least in the island monuments, of neolithic remains in the ground beneath the stone erections; the other, the peculiar nomenclature that the monuments have always borne. Celts, arrowheads, and similar relics are foond twenty feet below the soil, some of which are preserved in the museum of the Societte Jersiaise; in some of the cromlechs Phonician and Gallo-Roman remains have been found at a much less depth. The places were, therefore, the sepulchral areas of more than one set of human beings at successire periods; but the earliest must have been a people who did not work in

1 Instances of the sea retiring occor on the cosst of Kent; and when aided by the silt deposited at the month of rivers-as in the delts of the Ganges and the Mississippi - mag cause rery considerable accretion. 
metal, or (at the least) used stone implements for ceremonial purposes. As for the names of the monuments, they are doubtless Celtic, but such as woold be used by Celts who knew nothing of their origin, and looked opon them with ignorant and superstitious wonder; ti-korrigan, cor-gaur, ponque-laye. It is also noticesble that similar monuments are found in Syria and India; and it seems. probable, farther, that they were raised by slave labour, or by a people who employed a sabject proletariat.

Taking all these things into consideration, and observing, moreover, that the people of the islands are, in form and character, rather Breton than Norman, we may perhaps provisionally assume that the early population was either identical with, or subdued by, some race akin to the modern Basques of Languedoc and northern Spain, who were again overcome by a Celtic invasion and settlement. That the Celts did not exterminate the earlier inhabitants, may be inferred from the fact that the adjacent parts of the Continent were occupied by a mired race, admitted to have originated from a fusion of both. Later even than the Christian era, the south of Gaul and the north of Spain were occupied by the 'Celtiberians.' In the fourth century they had blended with the Gallo-Roman society, as we see from the statements of Ausonius the poet, born at Bordesur about 309 A.D. and profect of Latiom under the emperor Gratianas. Ausonius was evidently prond of being a 'Celtiber.'

Passing on rapidly we shall find that here, as on the mainland, there must have been a settlement in which the civilisation of the empire became predominant. That influence, however, belonged to its earlier, or pagan, period. There is no evidence of the introduction of Boman christianity such as occurred in Kent. The cross was planted in the islands by missionaries from Ireland and from Brittany ; and the Celtic bierarchy was centred at Dol. This was the period of Frankish ascendency, during which the island church was under Breton bishops although she ultimately became subordinate to the of Coutance. A persistent tradition points to the existence of a comparatively recent isthmus between Jersey and the Cotentin cosst; and it is said that the bishop of Coutance could cross by a temporary bridge when proceeding on his visitations." M. le Cerf even cites a charter to show that a chapel was boilt upon the Ecrehous at a still later period becanse the people could no longer attend divine service at Portbail on the mainland. But it is not generally believed by local antiquaries that his application of this document is correct. Be this as it may, there was close intercourse between the islands and the Frankish province of Neustria ; for German institutions were introduced in the archi-

$x$ A Roman toad is eren supposed to heve ron scross the Benfletins (see msp in Patriarche Akier's Tableaur). 
pelago which supplanted the Roman system there, as they did under the Saxons in Britain.

In all these changes the earlier races remained. There were new masters and there were more slaves; but it is not to be assumed that any race was exterminated. Not only did the Franks introduce their secular institutions and found a new spiritual jurisdiction; they waged war for their insular possessions against the pirates of the northern seas, the remains of whose camps and barrows are still to be seen. But there is no reason for supposing that Franks, any more than Romans, had to conquer the original population, much less to destroy them. The Romans slaughtered the Draids, and overthrew or otherwise obliterated their shrines and altars. But the fishermen, the agriculturists, the women and the children, must have been left to provide food and otherwise labour for the conquerors. If not, the latter would indeed have justified the trope which literary exigencies put into the mouth of Galgacus. And what the stern Roman did not attempt would hardly be done by the less organising Franks.

There is some evidence of a partial occupation by Saron and Danish rovers. Mr. Vigfusson finds mention of the islands in the Edda; and it is possible that they were used 28 a place d'armes by the ultimate conquerors of Normandy. Arms of that period have been found buried, especially in Guernsey.3 But one finds no further evidence of alteration in the ethnology of the islands between the beginning of the sixth century of the christian era and the annesation of the Cotentin by William Longsword, the second duke of Normandy, A.D. 932. It is generally assumed that the Normans now occupied the islands to such an extent that the population became Norman and has continued so ever siace. In proof of this it is observed that the family names are mostly of Norman origin, the Norman law is supreme, the French language is indigenous, the feudsl system is still in force. Modern research, however; has done much to weaken the force of these arguments. No doubt there are a good many Norman patronymics among the insular families; but it is perhaps enough to reply that inasmuch as family names were not introduced until some time after the Norman annexation, and when the French language had become general and the manors were held by Norman lords, family names would be sufficiently explained by such considerations. The supremacy of foreign law and language would be merely a badge of political supremacy and of a previous backward civilisation, and even so when looked into will be seen to have little real value. ${ }^{4}$ The French language must have come in during the five centuries, more or less, during which the islands had been under the Franks; and the law

\footnotetext{
- See Figfusson and Powell, Grimm Centenary Papers, No. 3.

- A namber of non-Argan and Celtic rords still linger in the islend French.
} 
is really a most risionary guide. The political institutions of the archipelago were, nay still are, rather Frank than Norman; and the Norman 'Customary' was not published until long after the final alienation from Normandy; never becoming statate in the islands.3 Eren on the mainland the old Gallo-Frankish population clang earnestly to their ancestral institutions, as is clear from Professor Freeman's account of the peasant revolt of A.D. 997. The same authority ('Norman Conquest,' i. 171) gives reason for believing that the Normsns on acquiring the province of Neustria not only did not extirpate the inhabitants, but adopted many of their institutions; and by the time when the Cotentin and islands were annexed the Normans had probably become still more Frank. The priests, magistrates, and antonomous communes of the people had been respected; Bishop Stubbs has shown that the constitutional tendency of the duchy was Carlovingian: "What little legal system subsisted was derived from the Frank institutions as they were when Normandy was separated from the Frank dominion' ("Constitutional History,' i. § 92). The feudal system itself was not of Norman origin; and, as introduced into the islands, was commercial rather than organic. The parishes did not become manors, nor did the Norman seigneurs usually reside in the islands. They drew rents as absentee landlords from the old allodial proprietors whom they had reduced to 80 much of dependence. But the island farmers have, perhaps, never abandoned their proprietary claims; and the chief positive outcome of the usurpation has been that the name of 'Norman' is opprobrious and hateful. There is an act of the Jersey Cour Royale, dated $18 \mathrm{Feb} .1539-40$, to the following effect : Guille Nycolle est condampré a Tamende pour ce que decant Justice le dit Nycolle arragantement sans cause a appellez Joln Hodon 'Normant et fils de Normant.'

Even so late as the Franco-Prussian war of 1870, the misfortones of the French were a source of rejoicing to their neighbours; and among the Jersey farmers a fresh narrative of defeat was met by the commentary: Tiens; v'là ces — de Normands rossés ocquo une fais. This traditional hostility (manifested in more than words on many occasions) dates from the times of the original occupation of the islands by the Normans, whose name is thus used as a generic term of abuse for all Frenchmen. The provocations received from Normandy must have been grest to cause such an hereditary hatred. But it is now evidently yielding to milder manners and better knowledge of the amisble character of the French. In the inquest made by Henry III there was no mention of Norman law or custom, either in writ or return. So far back as the reign of Edward II the royal commissioners sent to examine into the laws and rights of the islanders, were assured by them either that they had never

- The Grand Contumier is no dorbt evidence-prind facio-of what the lew was at the time of the separation under John; but it is not 'positive lsw' in the islends. 
been governed by Norman law, or that it had been with especial saring of customs and usages which had prevailed beyond the memory of man. Among these they reckoned self-government per optimates patrice; so that their institutions could hardly have been then regarded as an importation from the duchy.

If any further proof be required of the non-Norman origin of the balk of the Channel islanders, it may be observed that there are few traces of Norman architecture and no remains of any purely private castle, that sure sign of fendal conquest. A few Norman families must have, first and last, settled peacefolly in the islands. But that is not a proof of conquest or of extermination of the natives; 8 is clear from the case of Scotland, where Bruce and Campbell, Gordon and St. Clair are still among the chiefs of society, although it is certain that Scotland was never conquered or popalated by the Normans. A few of the Channel-island names are territorial, others are modern French or English. The rest are the usual survivals of nicknames taken from trades, occupations, or personal peculiarities, Le Feurre, Larbalestier, Le Gros, Le Brun, \&c.; or from offices, as Le Bailly, Le Vesconte.

For the first troubled period succeeding the expansion of Normandy, under the Conqueror and his sons, the islands continued an obscure section of the duchy. The lands were parted for administrative purposes into communes, in which some part was held in severalty and some in common. Twenty houses formed the fondamental group in Jersey, and each commune was made up of several vingtaines, divisions which are still preserved ; ${ }^{\circ}$ in Guernsey the group was only twelve. The chief authority was in a court of twelve magistrates, known in France as échexins, from the Germanic Schoeffen, or jurats from the Latin. The siternative titles show the composite origin of the institution, common to the north, or Frankish, Gad, and to Acquitaine. These were recognised institutions of the Carlovingian empire ; and there is no reason to doubt that they were respected by the Normans, as held by Dr. Stabbs. This was due partly to motives of policy, to which the Normans were generally accessible; partly also, it may be surmised, to Norman antecedents, which left those invaders without any prejudice in favour of institations of their own, or anght that they conld substitute for that which they found existing. Even in England, which was in some senses completely subdued, so masterfol a ruler as William the Conqueror respected the local usages of England; and it is not likely that the son of Rollo did less at a time when the Normans could have had no law of their own, and in a province which had not been forcibly subjugated. The islands, then, before Henry II must have enjoyed their own indigenous institutions.

It is stated in Falle's 'History' (the source of most of the cur-

' In St. Onen the divisions are called cueillettes ( $q d$. circles of collection). 
rent literature) that the institutions of the islands are based apon a charter given them by Fing John immediately after the loss of the mainland duchy. But this appears to be a myth resting on mere conjecture. The earliest documentary evidence-that of the inquest of 32 Henry III-does not show the people in the character of Normans claiming Norman institutions under such a charter, although many usages and customs are mentioned. In the commission issued by Henry to Richard de Gray, that governor is instructed to observe and administer the laws which were in use in the times of the king's grandfather, who became duke of Normandy in succession to his mother, the empress Maud, before succeeding Stephen on the throne of England. We are, therefore, safe in accepting the conclusion of Mr. le Quesne, that King John after the loss of the duchy 'may have confirmed the liberties of the people . . . but did not grant or originate them.' And these facts illustrate and explain the doctrine, laid down in Calvin's case, that 'the isles of Grarnsey and Jersey [are] parts and parcels of the dukedom of Normandy yet remaining under the actual leigeance and obedience of the king. . . These islands are no parcels of the realm of England, but several dominions, enjoyed by several titles, governed by several laws.' 7

The twelfth century is the beginning of the authentic history of these singular little states, model republics under royal protection. It was then that was originated their especial cognisance, formed of the two leopards, passant, of Normandy and one of Acquitaine, which, rather than the British escutcheon, is still their heraldic seal and bearing. It was then probably that the old commnnal divisions were formed into parishes for ecclesiastical purposes; indeed, the date of 1111 A.D. is popularly ascribed to the oldest of the existing Jersey charches.

During the troubled reign of John, the French made attempts upon the islands; and the celebrated naval commander of those days, Eustace le Moine, took part in the struggle, sometimes on one side, sometimes on the other. Of the administrative arrangements and the condition of the people we know bat little. Some of the seigneurs probably came over and settled; notably the ances. tor of the present house of St. Ouen, who derived his name from a fief on the coast of the Cotentin, Carteret near Portbail. For King Philip (when he declared the dakedom forfeit for John's failure to appear before him and answer to a complaint which, according to the latest theory, was not, as commonly stated, the charge of mardering his nephew, Arthar of Brittany) also pronounced the confiscation of the fiefs of the tenants-in-chief who might adhere to John. ${ }^{8}$ And of these the founder of the house of

7 Coke's Reports, 20 b.

- Doubt has been thrown on the exact nature of these procesdings by M. Bermont 
St. Onen was one. So that this family, whose distinction extends beyond the sphere of local story, derives its paironymic from a place with which its members have never had any connexion since, although it may be seen from the Jersey coast on any clear day.

All these seignears were probably originally the leading mem. bers of the legislature : indeed, the assise d'héritage, at which they were bound to appear, was the court at which political ordonnances long continued to be framed and promulgated. But they doubtless had for assessors the twelve jurats and the twelve rectors of parishes; the constables, or mayors of parishes, who now form the remainder of the official portion of the 'states,' being subsequently admitted as substitutes or deputies when the seigneurs ceased to attend. The bailiff ultimately became the head of the local magistracy ; but the governor, or captain, as a royal officerperhsps representing the primitive 'count' or missus dominicusoriginally held real, if undefined, power. In this office was vested the disposal of the public revenue, the right of presentation to parish churches, the appointment of fanctionaries whether civil or military, and the general control of the executive administration.

It is probable that the communes were never brought onder feudal obedience, as such; but that fiefs were created by the crown from time to time, and the old allodial proprietors induced by verious motives to admit the protection of the lords, without waiving their status as proprietors, and without incurring any of those military obligations which, in less fortunate conntries, usually formed part of the feudal tenure. The farms continued heritable and transferable, subject to money claims or charges in kind; and the armed levies were perhaps on a parochisl rather than a feudal basis, from which they ultimately developed into the modern militia. Five only of the Jersey fiefs were fiefs haubert or of knightservice, and these (though called 'noble') did not-as elsewheroconvey a title of honour.

The division into ringtaines, which still prevails in most parts of Jersey, and the titles of centenier and douzenier, by which the parish officers of both islands are still known, point to a time when

in a recent issue of the Reous Eristorique. Bat the point is not meteriel to the general statement given above.

- $\Delta$ an illnstration of the entiquity of this lemily may be cited the roport of the rojal commissioners of $2 \mathrm{Edw}$. I : Jurati de parrochid $\mathrm{S}^{\text {i }}$ Audaeni dicunt por sactamontum suam quad Reginaldus de Cartrut tenat quasdam landas ds domivioo regis pro voluntate ballivi reddendo inds anruatim vii. solidos of valent ic. solidi. Dicurt atian quod rex porcipit de feodo de Wynceles x. sol anrteatim per manum Johanris de Cartreto. Elsewhere: De feodis dicront $q$. foodum de Wynceleys debet plentem relevium

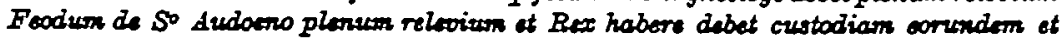
haredum et rodditus dominortom irffro atatom (V. Extorte de Pan 1974; second pablication of the Socitte Jersiaise.)

The fief of St. Onen is still held by a representetive of the house of De Carteret, who is also (1886) one of the jurate of the islend of Jersey. 
groups of householders were sssociated for purposes of self-government, which perhaps became obsolete ander the feudal system. ${ }^{10}$ Moreover the seigneurs held courts at which the landholders had to appear and make areu for their holdings; and some of the charges, in kind and in specie, have subsisted down to our own day, including the right of annee de succession. Under this custom the seignear takes the land of proprietors dying without issue, and enjoys the profits for a year and a day. This probably points to an early custom of annual division of tenure: an analogous right existed in Brittany under the name of droit de rachat.

Under such a mixture of allodialism and feudalism the islanders continued their humble existence. The land in each parish was originally more or less common, subject to periodical division, which tended, gradually, to become permanent and heritable along with the original severalty. Bat in each parish there remained, down to days still remembered, a communal plough; and by the law or custom of banon the members of the parishes had the right of turning their cattle loose, on a certain day, on fields from which the crops had been cut and carried. This custom was common not only to both the islands, but also to the mainland of Normandy, and is recorded in the 'Couttumier de Normandie.' There is no trace of a game law in the sense of an exclusive right of the seigneurs to hunt over the lands of the tensnts. There was a muitre des chasses, however, to watch over the crown warrens; and alike in Jersey and in Guernsey the right of sporting was restricted to the gentry, the manans being prohibited from encroaching on such privileges under distinct penalties. In the year 1526 an ordinance pras passed in Jersey fixing the fine for pursuing game, en quelque maniere que ce soit, at ten francs, a large sum considering the place and time. Such laws have, happily, become obsolete; and it is understood that no seigneur would now enter upon the lands of his farmers, for purposes of sport, until he had asked and obtained permission.

With this scanty account of the ariginal condition of island society, we must pass on to a few recorded events of history.

The original separation of the islands from the main duchy took place in A.D. 1203-4. M. Pégot Ogier has collected evidence of repested attempts to conquer them on the part of Philip Augustus, which were resisted with success." Under Henry III no affair of importance appears to have taken place, excepting always the inquest of the thirty-second year. During the latter part of Henry's long and unquiet reign the lordship of the islands was an appanage

\footnotetext{
w The use of a term indicating ' collection' in Bt. Ouen perhsps indicates that in thet manor the power of the seigneur was greater than elsowhere.

is Seo also Dupont's Histoirs du Cotentin (Caen, 1873).
} 
of the heir apparent; and there are still extant documentary proofs of the attention paid to them by that great statesman, afterwards Edward I. After he became hing, that care continued; and the quo warranto pleas of the beginning of the reign of Edward II arose, probably, out of a commission issued by that king's father. It has been already noted that, on this occasion, the people claimed the right of being administered by their own jurats, presumably elected, as an institation that had prevailed $a b$ antiquo, and a tempore quo non exstat memoria; and that the antiquity was admitted. Besides these general questions, the holders of the placita of those days heard and determined money claims as between the crown and the religions houses, and entertained complaints of private persons against the royal officers. Many churches were built on the islands during these early Plantagenet times, among which the most conspicuous is that of St. Peter Port, Gnernsey, dated L.D. 1312, still in fine preservation, and a grand monument of early flamboyent architecture.

An ertraordinary importance was attached to the possession of these islands, both on the French side and the English; a feeling, indeed, for which it is difficult to account, bat which mast be kept in view. Joined to the number of handsome places of worship, it seems to show that the islands were even then prosperous places, and it helps to explain the growth of privileges and immunities which have made the English Hesperides one of the most favoured spots of the globe. Reiterated charters and declarations of the English rulers avowed the loyalty of the people, and the sense entertained of that loyalty by the crown. Of the attempts made to restrain the oppressions of the local officials, the following example (taken from a letter of 10 Edward $I$ in the Patent Rolls) may be cited: Eiquitati dissonum ut qui ballias seu loca nostra tenent (quos ad justitiam exercendam et tenendam loco nostri ponimus) ad injurias faciendas prasumant extendere manus suas.

This extract appears to be regarded by an indefatigable local antiquary, Mr. H. M. Godfray, ${ }^{11}$ as an indication of the existence in the end of the thirteenth century of a judicial officer like the modern bailiff. It is, however, at least possible that the bail of those days was more of the nature of a farm of the civil administration of one of the islands, given for a money consideration by the royal governor. One of the definitions of the old French word bailli given by Littré is, officier de robe qui rendait la justice au nom d'un seigneur; and it is observable that the Guille de St. Remi, tenens balliam at whom the above censure was levelled, was attourne d'Othon de Grandison, the then lord governor or gardien des iles. It is, therefore, rather as bailli in the sense of farmer-delegate of the

1 The writer would, once for all, express his obligetions to this gentlemen, whose conscientions labours are destined to throw a permanent light on island history. 
governor (who may possibly have exercised some judicial functions), than as an officer answering to the 'bailiff' of the present day (a chief justice appointed by the crown), that we are to regard De St. Remi and his colleagues of the time of Edward I. Grandison appears to have been an absentee governor, who regarded the islands as a mere source of pecuniary profit, and the claims of his sons were altimately bought up for a compensation of a thousand livres in the reign of Edward III. 12

About 1396 trouble began to gather in the Channel. Darid Brace, the exiled king of Scotland, in the course of his altimately successful attempts to recover the crown, obtained the aid of the French hing, and fell apon the islands of Wight, Guernsey, and Jersey; on which Rex mandat quod homines eligantur, armentur, et in insulas Gerneseye, Jereseye, etc. mittantur, ad eas defendendas ab invasione sociorum Scotica. Four years later the ling complains of the atrocities of the Scots and their allies in Guernsey, interficientes quos illuc invenerant, atati, sexui, rel ordini non parcendo. Bahnchet, the French admiral (afterwards captared and hanged by the English), was particularly conspicuous in these cruelties. The document quoted by Mr: Tupper (' History of Guernsey,' 87) as evidence that the castle at St. Peter Port (Cornet) was held at that time for the English crown is an extract from the Parliamentary Rolls carelessly copied. It reslly refers to the sister island ; and for 'Gerneseye' we should read 'Gersuye' or some such word. It does not appear that the French were finally expelled from Guernsey till 1344; in 1389, when Tupper supposes it to have been recovered, it was evidently in the possession of the French, whose king granted it to his eldest son, John, by whom it was re-granted to the celebrated Marechal de Bricquebec. The chiefs of the Guernsey loyalists took refuge in Jersey, and finslly reconquered their own island with help from Jersey and from England.

By this time the separation of functions had, probably, taken place; the royal writs are regularly addressed to the 'bailiff and jorats ' on matters of civil administration; and the governor, or his lieutenant, appears only in a military capacity..$^{13}$

In $1350 \mathrm{a}$ daty was ordered to be levied for the fortification of the town of St. Peter Port; bat that town was again captured in 1372 by the maritime adventurer Evan of Wales. Sir Edmand Rose, or Rons, the English governor, was driven to take refuge in Castle Cornet; but the invader altimately retired. About the same time the castle of Gouray, in Jersey, was besieged by the French; but

12 Grandison's predecessor 28 parden of the isles was Arnald Jean, who is called 'King's beiliff' in the letters petent of 1275. He sppears to heve explojed deputies who are also called 'beiliffs' ( 0 . inquest of the same year. Soc. Jers publication).

"It is to be obserred that to this dey the bailiff is not elected, like the junats, and has not the same power in the cont, only roting when the jurats are equally divided. 
great uncertainty hangs over the affair; all that is clear is that this attempt also failed of success. The castle has since been known as Mont Orgaeil ; and it is possible that its name of pride was acquired from its having resisted a siege at a time when English prestige, generally, was at a very low ebb.

The good affections and services of the islanders were frequently scknowledged by the sovereign in these times. In July 1841 Edward III, ' considering with thankful remembrance how constantly and nobly our belored and faithful subjects of our islands of Jersey, Guernsey, Sark, and Alderney have continued in their allegiance, and what things they have endured for the preservation of the said ialands and the maintenance of our rights and honour ... secures them the same immunities and privileges which they had heretofore enjoyed. His successor renewed the testimony and grant. (See Tupper, 96, 118.)

In the Lancastrian period the islanders appear to have suffered the lot of the shattlecock between their two quarrelsome neighbours. In a great naval battle fought about 1403, the French were anusually successful; and having dispersed the English ships and massacred as many of their sailors as they could capture, fell upon the islands. The crstles held out, but great havoc was wrought upon the open country. Two years later a landing was effected in Jersey by Don Pero Nixo, a Castilian commander acting in alliance with France. A bloody but not very decisive battle was fought-a.s is generally believed-in St. Aubin's Bay, and the gallant leader of the Jerseymen (called 'Llamabule' in the Spanish chronicle) was left dead upon the sands with many of his followers. ${ }^{14}$ In the following reign the tables were turned, and the aggressive policy of Henry V protected the islands from attack. It is to this martial monarch that is assigned most of the earlier part of Mont Orgueil Castle on the east cosst of Jersey. His imbecile son and successor showed favour to the islands; ; indeed, it is noticesble that their best royal friends have been among the weaker of the kings of England. An inspeximus of Henry VI is said to have recited the charter of Richard II, and we have seen that the islands were also objects of solicitude to Henry III and Edward II. In the latter part of Henry VI's reign, however, this care obviously gave way to yet graver anxieties. In 1461 Queen Margaret ceded Jersey to Louis XI in consideration of a force sent to the succour of her side in the English wars. Pierre de Drenr-Bresé, count of Madlévrier, the seneschal of Normandy, conducted a semi-official expedition to England; and Surdeval, one of his lieutenants, occupying the castle of Gouray, Mont Orgueil, held power in the island for many years, though unable altogether to overcome the infinence of the Carterets

14 It has been suggested that there were two of thees attecks, one being on Guarnsey, and that they bsve been mired up in the narratives nenelly accepted. 
in the restern parishes. It is to this date that the moat and part of the masonry of the manor-house of St. Oden, their ancestral seat, are ascribed. A monument of the French occupation continued in existence many years; for so late as 1516 the royal commissioners of that era found a duty on corn levied by the 'Captain ' which, they reported, fuyt coinencé $p$. Les frauncoys au tems que Surderall fust Cappitaigne. 15 The actual occupation was put an end to early in the reign of Edward IV, when the castle was taken by Sir R. Harleston, vice-admiral of England, with aid from the seignear of St. Ouen.

In 1483 the clergy of the diocese of Coutances obtained from Pope Sirtus $\Gamma \mathrm{F}$ a bull confirmatory of the neutrality of the islands. This singular privilege is mentioned by many historians and jurists, from Camden and Selden to Falle; it continued in force down to the reign of William III, when it was abolished by an order in council, having long been disregarded by the islanders themselves, who found it a check upon privateering. While it continued in force it had the effect of preventing, or impeding, hostilities within sight of the islands, and giving much protection to locsi commerce. In 1549, two years after the accession of Edward VI, Sark was occupied by the French, who made an attempt on Guernsey from that island. Defeated by the vigilance and valour of the people, they next attacked Jersey, but with no better result; and Sark was soon afterwards recovered by England. Aided by the pope, Henry VII weakened the jurisdiction of the feudal landlords, and confirmed the parochial administration of the levies, thus laying the foundation of the modern militia.

The Reformation took root and flourished rapidly in the islands, espocially in Guernsey, where a large immigration of French protestants had already begun before the Marian persecution. The catholic reaction also reached them, as the well-known account of the shocking martyrdom of Perotine Massey in Foxe is enough to show. The French at this period had possession of Alderney, from which they were expelled in the following reign by Sir Leonard Chamberlain, whose son was granted the farm, or perhaps seigneurie, of that island. During the long reign of Elizabeth, it is evident that the islands shared in the common prosperity. The last shred of English territorial aspiration on the continent of Europe being now gone, the archipelago berame an element of another sort in the national life. Once it had formed a material monument of the dukedom out of which the royal power had grown, and seemed to afford stepping-stones for a victorious return there. Now that Calais was lost, and that the new monarchy was erected in the place of the Norman fendalism, all this was forgotten: The

is The common story, in Falle and elsewhere, that the Carterets kept the French ontirely out of the six western pariahes, is disproved by a precept from Louis ordering Mealovier to release the priory of St Peter, which ho hed seirod. 
islanders had become Calrinists, too; and it was no longer either seemaly or politically expedient that they should remain subject to a bishop who was both a papist and a foreigner. Accordingly, in the early part of the reign (A.D. 1568), when Paulet or Powlett, the last Romish dean, was deposed, if not dead, the spiritual jurisdiction of the bishop of Coutances was ousted and the archipelago made part of the diocese of Winchester.

Other acts of Elizabeth are the foundation in Guernsey of the still flourishing college (A.D. 1563); the grant of Sark to the Carterets ; and the improvement of the castle in St. Helier's harbour, Jersey, which (like the Guernsey college) has ever since borne the name of the virgin queen. She also issued an inspeximus of previous charters, and bore the usual witness to the loyalty of the islands. The reign of James I is chiefly noticesble for the introdaction of episcopalianism into Jersey. Heylin relstes how this was done by the help of intrigue and personal motives. In Guernsey presbyterianism held out better; and the English charch was only grudgingly accepted after the Restoration in that island.

In 1610 the bailiff of Guernsey was Amias de Carteret, seigneur of Trinity Manor in Jersey. He was appointed lieatenant-governor by Lord Carew of Hopton, the official enjoying the dignity and emoluments of governor; and his appointment in Guernsey is noticeable for more reasons than one: showing, as it does, that a native of one island could hold office in the other, and also that the daties of lieutenant-governor and bailiff were not deemed incompatible. So late as the beginning of the eighteenth century, these offices were again united, in Guernsey, in the person of Sir Edmund Andros.

In the early part of the reign of Charles I, the French threatened to attack the islands, in retaliation for Buckingham's expedition upon their cossts. In consequence of this, additions and improvements were made in the castle of Elizabeth at St. Helier. That incommodions fortress-where the quartered English and French arms of Queen Elizabeth, and the three swordsin-pile of the Paulets, are still to be seen sculptured on the masonry - was twice the palace of Charles's son, once as prince of Wales, and once as king, de jure of Grest Britain and Ireland, de facto of Jersey. Here too was began the 'History of the Rebellion;' Hyde lived in 'the lower ward' as a guest of Sir George Carteret, the royalist governor, for nearly two years. It is at first sight singular that, while Jersey was, on the whole, royalist during the trouble of those times, Guernsey was generally well affected towards the popular cause; but the explanation is to be found in the religions difference, of which traces long remained, and are perhaps even yet not wholly lost. In 1692 Canon Falle could boast, in a Jersey pulpit, that the population of the island were all of the church of England, and 
' there is not one separate sect of any congregation whatsoever in the whole island.' The ase of the liturgy was, however, opposed in Guernsey for a very long time; so late as 1755 the dean was obliged to have recourse to the aid of the magistrates when reading it in the town church.

In spite of the whig tendencies of his island during the great rebellion, the Caralier lieutenant-governor of Guernsey was able to hold out in Castle Cornet by the help occasionally sent him from Jersey; and it was not until the larger island had been forcibly invaded and conquered by a squadron of Blake's ships and a brigade of Ironsides, that the place surrendered after a siege that lasted almost as long as that of Troy.

Of the general political condition of the islands in the serenteenth century, and of "their affection towards England, let the following, from the royal chaplain, Dr. Peter Heylin, suffice:

The people live, as it were, in liberd custocid, in a kind of free subjection, not any way acquainted with taxes . . . insomuch that when the parliaments of England contribute towards the occasion of their princes there is always a proviso in the act, "That this grant of subsidies, or anything therein contained, extend not to charge the inhabitants of Guernsey and Jersey ... \&c.' These privileges and immunities (together with divers others) ... hsve been a principal occasion of that constancy wherewith they have persisted faithfully in their allegiance, and disclaimed even the very nsme and thought of France . . . so much doth liberty, or at the worst a gentle yole, prevail apon the mind and fancy of the people.

It may be added that in Heylin's time the population of Guernsey-perhaps including the minor isles that constitute the bailiwick一was estimated at 20,000, and that of Jersey at $30,000 .^{16}$ In other respects Guernsey was by far the more prosperous and (as we should now say) progressive of the islands.

The trestment of the islands by Cromwell, in spite of the trouble that they had given, was both constitutional and considerate. From Burton's Diary (quoted by Mr. Tupper) we find that in 1654 they were exempted from sending members to Westminster, 'because not governed by our lsws, but by municipal institations of their own.' In 16.56 they were similarly exempted from the incidence of the excise.

Charles II wisely took no notice of the parliamentary proclivities of either the majority in Guernsey or the minority in Jersey, bat confirmed the ancient privileges of the islands. The French continued their designs upon them; but the only serious attempt that they made was frustrated by friendly information conveyed to one of the clergy by the Hugaenot wife of Turenne, and by the loyalty of

14 These extimates were, doubtless, very much in excess of the real figaresv. table belor, p. 37. 
the rebel general, Lambert, who was a state prisoner in Guernsey. Under James II we hear only of a bold attack mado in Guernsey upon the papist portion of the troops, who were disarmed by the protestant party on the eve of William's accession.

The reign of William III was memorable for the signal victory of the British navy at Cape la Hogue, largely due to the enterprise of Mr. John Tupper of Guernsey, who contrived to elude the French fleet in bis yacht, and bring intelligence to the British admiral. It Was doring this reign that the business of privateering began to be seriously renewed ${ }^{17}$ by the islanders, who are said to have captured 1,500 French prizes during that comparatively short period. They carried on this trade throughout the eighteenth century with such success as to win from $\mathrm{Mr}$. Burke the title of 'one of the naval powers of the world.'

In 1778, while the American war was at its height, the French made a serious attempt to land in Jersey, their force being commanded by a cadet of the princely house of Nassan, who held a commission in the French army. The landing was successfally opposed. In January 1781 a subordinate of Nassau's, by name Macquart, a broken gamester of the Cassanopa type, made a desperate attempt on the town of St. Helier, in which, if successful, he would doubtless have been supported by a large French force. Macquart, who is known in history by his assumed title of Baron de Rallecourt, was shot on the market-place of the town, now the Royal Square, and those of his men who survived the brief engagement were sent as prisoners to Portsmouth. The victory was greatly due to the steady valonr of the Jersey militis, of whom Dumouriez reported at the time that they were such good marksmen, and so deroted to England, that it would require ten thousand good troops to conquer the island.

Since that date the loyalty of the people has not been exposed to any renewal of these rude trials; but they continue faithful and resolute, as may be seen from a ballad by the late Georges Métivier, of Guernsey, which may also be cited as a specimen of the local language:

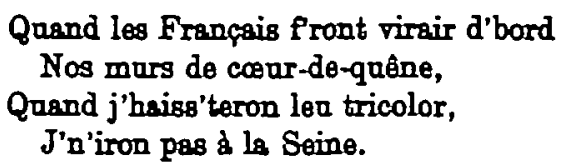

In recent times this spirit has been again acknowledged by Engligh ralers. King William IV honoured them by declaring their militia regiments 'royal,' and by appointing an officer of each island to be a royal aide-de-camp. Her present majesty visited the islands early in her reign, and paid them similar compliments.

if Sir George Curteret's piracies, under the Commonwealth, are of course well boom. 
It only remains to conclude this unaroidably concise record by a brief mention of some of the distinguished men whom the islands have at various times produced. In order properly to explain this, it is necessary to remind the reader how very small the numbers of the people have always been.

In the two bailiwicks the popalation has stood, at various times, at the following figures:

\begin{tabular}{|c|c|c|c|c|c|}
\hline \multicolumn{3}{|c|}{ Gotrarts. } & \multicolumn{3}{|c|}{ Junter. } \\
\hline A.D. & Torn & Totel & L. & Town & Total \\
\hline $\begin{array}{l}1615 \\
1727 \\
1800 \\
1871 \\
1881\end{array}$ & $\begin{array}{r}1,800 \\
4,600 \\
8,450 \\
16,166 \\
16,658\end{array}$ & $\begin{array}{l}8,000 \\
10,500 \\
16,165 \\
30,593 \\
32,607\end{array}$ & $\begin{array}{l}1692 \\
1794 \\
1806-15 \\
1871 \\
1881\end{array}$ & $\begin{array}{c}\overline{7}^{*} \\
\overline{7000} \\
30,756 \\
28,020\end{array}$ & $\begin{array}{l}15,000 \\
20,000 \\
22,855 \\
36,627 \\
52,446\end{array}$ \\
\hline
\end{tabular}

In the seventeenth century, therefore, the total of the archipelago wss probably under 25,000 souls, what would now hardly constitute an elective integer in England. Among those then produced by this tiny community were George Carteret, who, after administering the affairs of Jersey in times of great trouble, and defending the island valiantly against the invincible Cromwell, became vicechamberlain of the royal household, treasurer of the navy, lord of the admiralty, member of parliament, and commissioner of the borrd of trade; Daniel Brevint, desn of Lincoln; John Darel, dean of Windsor; Philip Falle, canon of Durham and chaplain to William III; and Edmund Andros, who, after filling the post of governor-general of New England (with which were included New Jersey and New York), died beiliff and lieutenant-governor of his native island.

In the following centary the islands produced, among other important persons, Vice-Admiral Philip Durell ; Morant, the historian; Admiral Carteret, the circumnavigator; Dr. James Bandinel, the Bampton lecturer : and Jean, the painter: the famous Lord Granville, secretary of state and viceroy of Ireland, was of the St. Ouen family, though not born in the island. Major-general Sir I. Brock, the heroic governor-general of Canade, who died in the arms of victory in 1812 ; Dobree, the collaborator of Porson and regius professor of Greek at the university of Cambridge; John Macculloch, the geologist; the Le Marchants, father and sons; and Admiral Lord de Saumarez, were all Channel islanders. Among minor or more recent celebrities may be mentioned Lempriere, author of the 'Clasical Dictionary;' James Amiranx Jeremie, regius professor of divinity and dean of Lincoln; not to mention the names of

3s $\nabla$. declaration of 1652 .

19 Idd soldiers, sailors, and strangers, say 3,000 , or total 19,000 (Stiles). 
persons now living. This is but an incomplete list; yet few English boroughs or even counties could compete with it.

We hare only had space for a very brief summary of the characteristic facts of this curious episode of feudalism. Whatever be the origin of Channel Island institutions; it is evident that they had been a perpetaal care and object of favour to the kings of the old monarchy. With the Tudors began the dawn of modern society; and the repression of the old aristocratic spirit found an echo on these remote rocks. The power of the seigneurs was curbed, the local levies were taken out of their hands and made into rudiments of the militia force now existing. Originally organised on the basis of the parish, each company was put under the command of parochial captains, probably elected by the people..$^{20}$ In the reign of Henry VIII a quarrel between the royal governor of Jersey (Sir Hugh Vaughan) and the bailiff (Helier de Carteret) led to the discomfiture of the former and favoured the growth of that independence which now distinguishes the bailiff's office. In the end of Elizabeth's reign Sir Walter Raleigh was governor of Jersey, and there set on foot reforms, among which was a system of registration for property which is still in operation. The royal court of Guernsey, in the next reign, had monopolised the power which ought to belong-and in Jersey does belong-to the 'states" or representative assembly: the functions of the Guernsey states are practically suspended, except in regard to the election of officebearers and the voting of supplies.

The Reformation took root naturally, and no religions crisis of an acute nature disturbs the annals of the islands or the traditional feelings of their present inhabitants. The great stiruggle of the serenteenth century passed off in the same unrancorous manner. After Cromwell had reduced Jersey, Carteret was treated very differently from the unlacky defenders of Drogheda; and Michael Lempriere, who became bailiff, exercised his influence in favour of moderation. No blood was shed, and the Cavaliers of the island were permitted to compound for the retention of their property. The cause of this difference is not far to seek; it is the absence of religious animosity such as had laid Ireland waste in 1641, and is, therefore, characteristic of Oliver's nature, stern but just. The islands, as we have seen, continued to be considered during the Commonwealth, being excluded from a parliamentary redistribation bill and from the excise, in both instances out of express deference to their ancestral immunities. Under the Restoration these privileges were secured afresh, while the organisation of the militis was undertaken in a spirit of seriousness unusual in that frivolous age. The then governor, Sir Thomas Morgan, was a brave old Cavalier; and in view of threatened attacks from France he

$\Rightarrow$ In 1545 the protoctor Somerset ordered this organisation by parish companies. 
reformed the militia, combining the parochial companies so as to make five regiments of infantry (clothed in scarlet) with two troops of horse guards and a train of artillery whose guns were kept in the parish churches.

In 1771 some legal and administrative measures were introduced in Jersey, and that island, by the introduction of a number of elected depaties into the legislature in the present century, is now politically ahead of Guernsey.

Thas it will be seen that, on the whole record, a singular fact emerges. These insular fragments of the duchy from which the feudal monarchy of England arose are the parts of the realm in which feudalism has become least oppressive and autonomy most complete. While the larger country has retained its game laws and its quasi-feudsi relations of landlord and occupier, the islands have only kept the more picturasque elements of feudalism. In Great Britain and Ireland the land became all feudal except such portions as were held in franc-almoign, and the feudal system still affects land tenure and agriculture at large. The only parts of those kingdoms which escaped are the Norse archipelago of Shetland and Orkney, where those fragments of ancient Scandinaria, in common with the continental fatherland of the Normans, never adopted the system which is connected in our minds with the Norman name.

The Channel archipelago, on the other hand, fell into a mixed condition. The prevalence of feudalism in the adjacent countries ultimately proved sufficiently strong to lead to the creation of fiefs upon the island territory. But the allodial tenure and some part of the commanal organisation remained, and, in their modern forms, are now stronger than the veneer of feudalism which the Franks and Normans at one time superimposed. The people have regained the whole local military power; the seigneurs, as such, have lost their seats in the legislative body. Their own courts, with aceux, reliefs, \&c. have been so dealt with that they do not clash with the rights of the yeomen; the wealth of the islands is distributed in a fairly equable way; there is no pauperism among the rural population, no political disaffection, and no crime.

H. G. KeENE. 